\title{
Paleoúdolí Doubravník-Borač ve světle elektrické odporové tomografie (ERT), jeho 3D model a vazba na hydrogeologický rajon 2242 (Kuřimská kotlina), karpatská předhlubeň
}

Paleo-valley Doubravník-Borač in the light of electrical resistivity tomography (ERT), its 3D model and connection to hydrogeological district 2242 (Kuřimská kotlina), Carpathian Foredeep

\section{Jan Vít ${ }^{1} \rightrightarrows$, Jan Jelínek² ${ }^{2}$ Zuzana Skácelová ${ }^{3}$ Pavla Tomanová Petrová1, Helena Gilíková'}

'Česká geologická služba, Leitnerova 22, 65869 Brno

${ }^{2}$ Česká geologická služba, Klárov 3, 11821 Praha

${ }^{3}$ Česká geologická služba, Erbenova 348, 79001 Jeseník

Key words:

3D model of the paleo-valley, electrical resistivity tomography (ERT) measurements, morphostructural analysis, digital terrain analysis (DMR) 5G, geological mapping, Cenozoic sediments, thickness of Miocene sediments, hydrogeological district 2241 - Kuřimská kotlina, Carpathian Foredeep

凸 jan.vit@geology.cz

Editor:

Milan Geršl

\section{Doporučená citace článku:}

Vit, J., Jelínek, J., Skácelová, Z., Tomanová Petrová, P., Gilíková, $H$. (2021). Paleoúdolí DoubravníkBorač ve světle elektrické odporové tomografie (ERT), jeho 3D model a vazba na hydrogeologický rajon 2242 (Kuřimská kotlina), karpatská predhlubeň. - Geologické výzkumy na Moravě a ve Slezsku, 28, 1-2, 33-43.

https://doi.org/10.5817/GVMS202114435

\begin{abstract}
There is a narrow depression of the relief between Doubravnik and Borač villages situated on the contact between the Bohemian Massif and Carpathian Fordeep of the Western Carpathians. Depression is mainly filled with Lower Badenian marine sediments, to a lesser extent also with Quaternary sediments of alluvial cones, loess and slope (colluvial) deposits. Current reflections on origin of the depression oscillate between the idea of an abandoned pre-Badenian valley of the Svratka River after a depression caused by purely tectonic processes. Disadvantage of the existing assumptions is that they rely on a minimum of objective data, especially in terms of thickness of sediments and the shape of the buried relief. The aim of this study is to increase knowledge about the tectonic structure, extent and thickness of sediments. Morphostructural analysis, field research and especially geophysical measurements (ERT) on 13 profiles with lengths of 81 to $595 \mathrm{~m}$ and a depth range of up to $65 \mathrm{~m}$ were used for this purpose.
\end{abstract}

The work confirmed that the studied area is probably a paleo-valley of the Svratka River, which is divided by faults into several segments. The most significant appears to be the tectonic zone in the area between Borač and Maňová. In the interpreted results of ERT measurements, it manifests itself in a rapid change in the thickness of calcareous clays as on the D05 profile, the bottom of the valley was found at about $285 \mathrm{~m}$ a. s. l., while from other profiles towards Borač it is certain that the bottom altitude is at least $30 \mathrm{~m}$ lower (and tertiary sediments width on the surface section is bigger).

What is the position of the rock bottom of the depression at the site of the divide with the D14 profile could not be determined, but it is definitely situated at a depth greater than $310 \mathrm{~m}$ a. s. l. From the profiles led directly in Doubravnik (D01, D02, D15) it is clear that the deepest part of the valley filled with Lower Badenian sediments is situated $W$ of Doubravnik church, but towards the north it turns to the east. The bottom was not found, but it is lower than $270 \mathrm{~m}$ a. s. .

Overall, it is possible to summarize that within the section between Doubravnik and Borač, the deepest shape of the relief is formed by meandering depression. Its position is different within today's shape of the relief depression. The situation is similar in the direct parts of the Svratka valley north and south of this area of interest (between Nedvédice and Doubravník and between Borač and Štépánovice). Therefore, the hypothesis of a paleo-valley of the Svratka River seems to be very probable. The diversion of today's flow of the Svratka River between Doubravnik and Borač to the current valley was caused by horst uplift and the overall change in the slope of the area after Badenian regression. There are also some hydrogeological impacts of this study. It is clear, the groundwater source (well HBV-1) is not situated in the deepest part of the valley, where sandy layers can be assumed, similar to that in Nedverdice (north from the area of interest). Besides groundwater flow under Badenian clays into hydrogeological district 2242 - Kurimská kotlina (south from the area of interest) from more distant parts of the Svratka River drainage area can be supposed, as the bottom of the Tertiary paleo-valley between Doubravník and Borač is not raised 
above the level of the floodplain. Also a significant failure of the underlying rocks at the contact of the Svratka Crystalline complex and the Moravicum (crystalline complex) certainly allows an uninterrupted overflow of groundwater under the insulator of Badenian clays.

3D model is disponible on https://geology.maps.arcgis.com/home/ webscene/viewer.html?webscene $=c 2 b b d 5 d e 2 c 1 c 4 f 13 b 34119 a d d 5$ 6501e7 (and other from the Czech Republic: www.geology.cz/3d).

\section{Úvod}

Na východním okraji Českomoravské vrchoviny, cca $9 \mathrm{~km}$ sz. od Tišnova, se nachází mezi Doubravníkem a Boračí protáhlá deprese v reliéfu (obr. 1). Studované území se vyskytuje v těsné blízkosti hydrogeologického rajonu Kuřimská kotlina (2242). Kuřimská kotlina je součástí karpatské předhlubně a představuje silně tektonicky postižené území, rozčleněné na řadu úzkých, místy hluboce zaříznutých údolí, dnes vyplněných miocenními sedimenty s různou úrovní denudace (Vít et al. 2017).

Zájmové území je litologicky, stratigraficky a tektonicky velmi složité - a to jak $\mathrm{z}$ pohledu litologie a stratigrafie, tak i tektoniky. Názory o vzniku tzv. suchého údolí mezi Doubravníkem a Boračí oscilují mezi interpretací o existenci starého předbadenského údolí, které dnešní tok řeky Svratky opustil (např. Novák 1924), po práce předpokládající čistě tektonický původ této geomorfologické struktury vyplněné spodnobadenskými sedimenty (Hrádek 1980). Všechny doposud publikované práce mají spíše popisný charakter nebo využívají geomorfologických

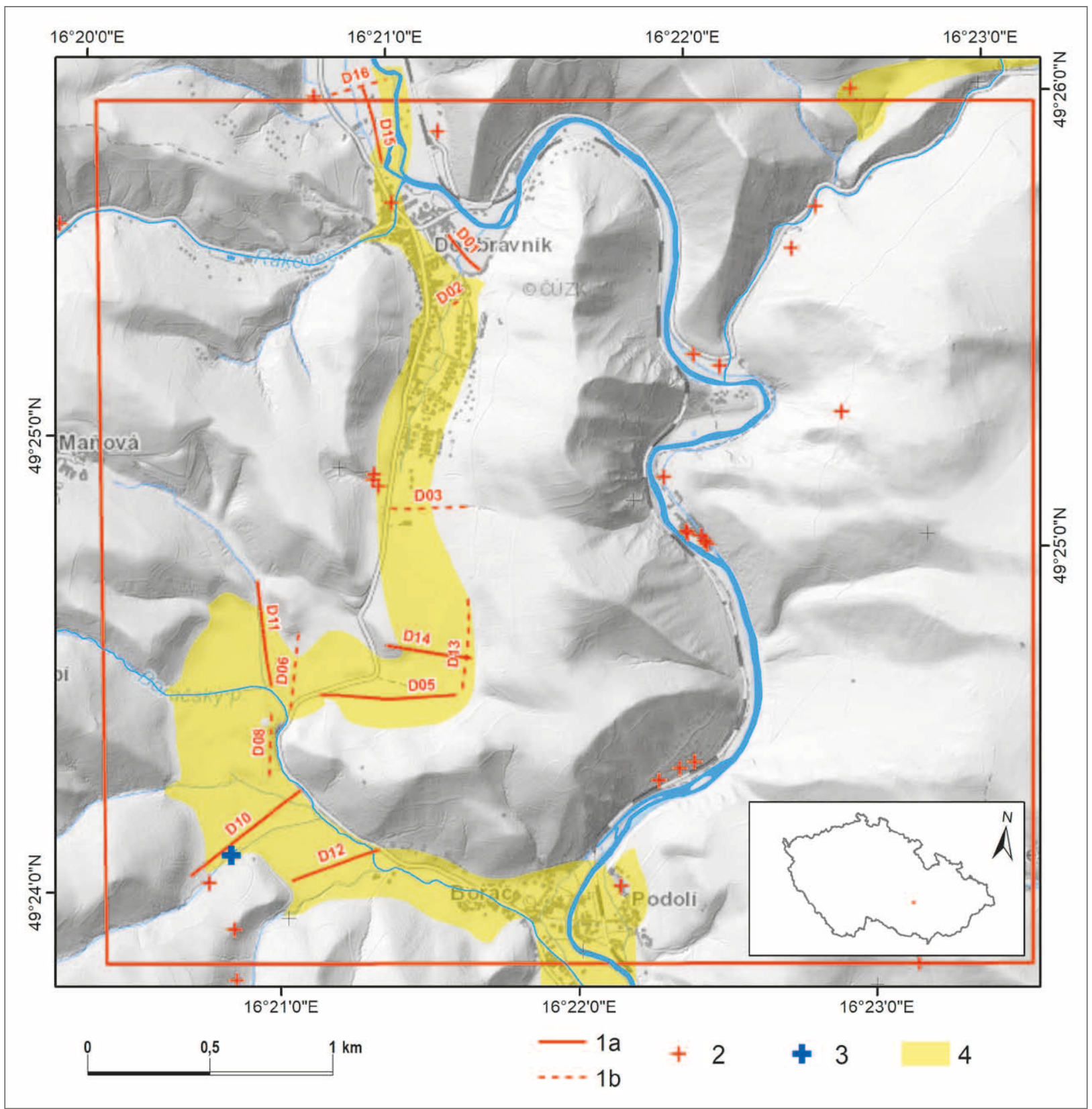

Obr. 1: Vymezení zájmového území. Legenda: 1 - pozice ERT profilů (1a - uvedeny v článku, $1 \mathrm{~b}$ - v elektronické př́loze); 2 - pozice vrtů (archiv ČGS); 3 - pozice hydrogeologického vrtu HBV-1; 4 - předpokládaný rozsah neogenních sedimentů.

Fig. 1: Studied area. Explanations: 1 - ERT profiles (1a - in the paper, $1 \mathrm{~b}$ - in the electronic supplement); 2 - boreholes position (records from archive ČGS); 3 - position of the hydrogeological well HBV-1; 4 - assumed extension of Neogene sediments. 
pozorování, vyhodnocení morfostruktur nebo uvažují o souvislostech s výsledky starších vrtných prací, většinou ze širšího okolí (Brzák 2001; Žížala a Vilímek 2011). Dosud zde prakticky neexistují podrobnější údaje objasňující litologii a hlavně mocnost výplně. Výjimkou je vrt záložního vodního zdroje pro obce Borač HBV-1 (Cahlíková 2012). Vrt byl situován při vyústění potoka od obce Husle, kde pod $6 \mathrm{~m}$ hlinitopísčitých aluviálních sedimentů byl zjištěn júl, v němž směrem do hloubky přibýval podíl úlomků rul (max. 15\%) a křemene. V podloží, od 30m hloubky, se vyskytovaly ruly. Další práce, které naznačovaly větší hloubkový dosah miocenních sedimentů, jsou až z míst vzdálenějších - výkop studny nad nádražím v Nedvědici
(Polák 1960) a vrty inženýrskogeologického průzkumu u Nových Štěpánovic. Vrty hloubené pro variantu II plánované 30 m vysoké sypané zemní hráze zastihly největší mocnost neogenních sedimentů ve vrtu V-9 situovaném ve výplavovém kuželu Kalského potoka (Schütznerová-Havelková 1969).

Tento příspěvek shrnuje výsledky studie, která měla za cíl s pomocí analýzy dat dálkového průzkumu Země (DPZ), nástrojů morfostrukturní analýzy, terénního geologického průzkumu a následném využití metody elektrické odporové tomografie (ERT) zachytit v oblasti mezi Doubravníkem a Boračí (obr. 1) průběh protáhlé deprese vyplněné miocenními sedimenty. Současně bylo

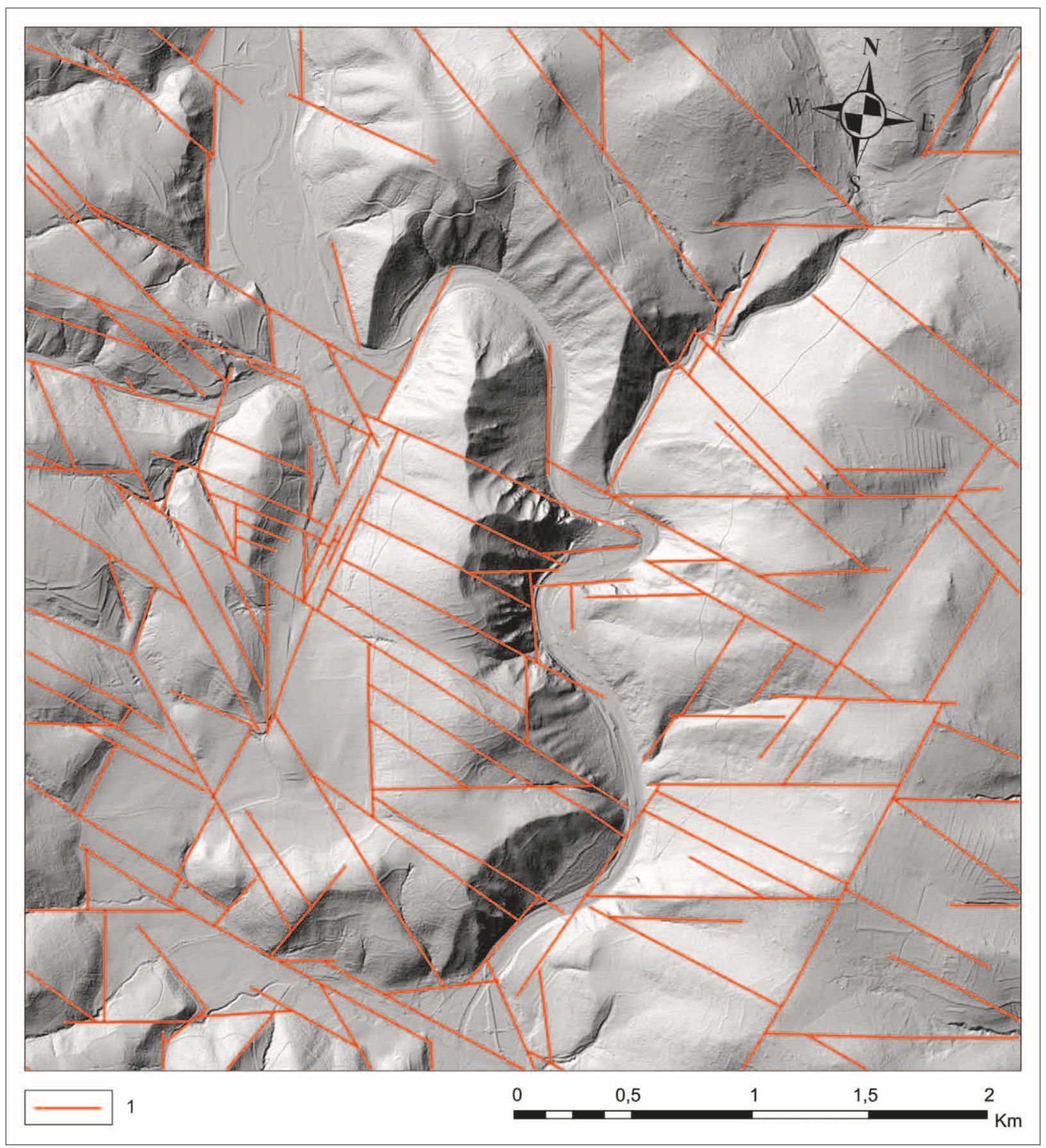

Obr. 2: Výsledná sít morfolineamentů (červené linie - 1) vstupující jako podklad tvorby 3D modelu detailního území. Fig. 2: The resulting network of morpholineaments (red lines - 1) is a basis for creating a 3D model of the detailed area. 
Tab. 1: Seznam měřených profilů s uvedenou délkou profilu a hloubkovým dosahem měření.

Tab. 1: List of measured profiles with the profile length and measurement depth range.

\begin{tabular}{|c|c|c|}
\hline Název profilu & $\begin{array}{c}\text { Měřená délka } \\
(\mathrm{m})\end{array}$ & $\begin{array}{c}\text { Hloubkový dosah měření } \\
(\mathrm{m})\end{array}$ \\
\hline D01 & 195 & 40 \\
\hline D02 & 81 & 15 \\
\hline D03 & 315 & 65 \\
\hline D05 & 555 & 65 \\
\hline D06 & 315 & 65 \\
\hline D08 & 275 & 55 \\
\hline D10 & 595 & 55 \\
\hline D11 & 435 & 65 \\
\hline D12 & 395 & 55 \\
\hline D13 & 395 & 55 \\
\hline D14 & 355 & 55 \\
\hline D15 & 315 & 65 \\
\hline D16 & 235 & 55 \\
\hline
\end{tabular}

za úkol zjistit jejich mocnost a litologii a v neposlední řadě interpretovat hlavní tektonické linie, které ji spoluvytvářely. Na základě terénních pozorování, morfostrukturní mapy a geofyzikálních měření byla sestavena geologická mapa zájmového území dokládající rozšíření miocenních sedimentů. Doplněním údajů o průběhu dna, které byly dosud zcela neznámé, bylo možné přispět k řešení geneze této zajímavé geologicko-geomorfologické struktury a tím $\mathrm{k}$ upřesnění její vazby na hydrogeologický rajon 2242 - Kuřimská kotlina.

\section{Metodika provedených prací}

Ve studované oblasti nebyla dosud vytvořena geologická mapa v měřítku 1:25 000, ze které by bylo možné pro detailní geologický popis převzít litologická rozhraní a zlomovou sít. Bylo tedy nutné $\mathrm{k}$ sestavení podrobné geologické mapy území zmapovat rozsah sedimentárního pokryvu. Zjištěné povrchové výchozy miocenních sedimentů byly popsány, zdokumentovány podle klasických geologických metod. Dva vzorky (označené DJ001 a DJ002) byly podrobeny mikropaleontologické analýze. Byly vyplaveny na sítu o velikosti ok $0,063 \mathrm{~mm}$, před plavením byly namočené do roztoku jedlé sody. Získané výplavy byly pozorovány pod binokulárním mikroskopem a následně determinovány. K vyhotovení mapy předpokládané hloubky paleoreliéfu, které sloužily k lokalizaci plánovaných geofyzikálních profilů, byly využity výsledky starších vrtných prací, i když jejich počet a prostorové umístění měly jen omezený význam.

Na širším území v okolí Doubravníku a Borače byla vytvořena metodami DPZ sít morfolineamentů (výrazně lineárně uspořádané tvary reliéfu) a zobrazena na současný reliéf (povrch DMR 4G). Morfolineamenty (obr. 2) mohou představovat schematické znázornění předpokládaných poruchových zón. Ty byly v kombinaci s geologickou situací a terénními poznatky využity pro plánování geofyzikálních měření. Následně byla zpracována morfostrukturní analýza (soubor metodických postupů objasňující vztah mezi reliéfem a geologií jako např. analýza údolní sítě, říčních teras, zlomová a puklinová analýza). Sít morfolineamentů byla detekována a extrahována souborem semiautomatických analýz a na základě vizuální detekce zjištěných morfostruktur z DMR viz Demek (1972). Přesný postup tvorby sítě morfolineamentů je popsán například v práci Jelínek (2008). U vybraných morfolineamentů byl vizuálně posuzován jejich přesný průběh. Hledané prvky nalezené na linii morfolineamentu byly označeny jako body v modelu, které následně posloužily k automatickému vymodelování vlastní plochy každého zlomu. Kombinací těchto dat s výsledky geofyzikálního průzkumu a terénního výzkumu bylo možné identifikovat hlavní zlomové struktury a automaticky vymodelované zlomové plochy přesně dotvořit do podoby konkrétních zlomových ploch pomocí modelovacího software MOVE 2018. Vytvořené zlomové plochy byly nezbytné pro konstrukci 3D modelu paleoúdolí.

Geofyzikální měření mělo za úkol zjistit mocnost sedimentů a tvar reliéfu paleoúdolí. Č́stečně byla využita i gravimetrická mapa oblasti (Sedlák et al. 2006), ve které se strmým gradientem projevuje okraj údolí a tíhovým minimem jsou indikovány jednotlivé deprese vyplněné „lehčími“ sedimenty. Použitá geoelektrická odporová metoda ERT umožnila konstrukci odporových řezů $\mathrm{v}$ liniích zkoumaných profilů. Interpretace těchto řezů vychází z rozdílů zdánlivých měrných odporů zachycených geoelektrických vrstev a z jejich vzájemné pozice v odporovém řezu. Metoda ERT využívá kombinaci odporového profilování a sondování tzv. multielektrodové uspořádání, kdy jsou jednotlivé elektrody používány jako zdrojové a měřící a připojeny $\mathrm{k}$ automatické multikanálové měřící aparatuře. Vlastní měření bylo realizováno pomocí přístroje ARES II od firmy GF Instruments s. r. o. Během terénních prací bylo proměřeno celkem 13 profilů metodou ERT (roztažení typu „Schlumberger HD“, které velmi dobře indikuje horizontální a mírně ukloněné rozhraní) v délkách 81-595 m (obr. 1, tab. 1). Pouze profil 10 bylo možné vést přes místo $s$ ověřenou geologickou stavbou, a to v blízkosti hydrogeologického vrtu HVB-1 (Cahlíková 2012). Jednotlivé elektrody byly od sebe vzdáleny $5 \mathrm{~m}$ (kromě profilu P2, kde byl krok $3 \mathrm{~m}$ ), hloubkový dosah měření byl, v závislosti na délce profilu, až $65 \mathrm{~m}$. Délka roztažení byla pro každý profil volena tak, aby byl dosažen požadovaný hloubkový dosah, nejčastěji bylo zapojeno 64 elektrod (délka $320 \mathrm{~m}$ ) a využita metoda rolování. Data metody ERT byla zpracována programem RES2DINV (Geotomo Software), v němž byla také zohledněna topografie terénu.

Veškeré poznatky z geologického mapování a terénního výzkumu, ERT měření a morfostrukturní analýzy byly zpracovány a vizualizovány $\mathrm{v}$ podobě $3 \mathrm{D}$ modelu zájmového území v softwarovém prostředí MOVE (Petroleum Experts Ltd.). Vstupními daty pro tvorbu modelu byly DMR 4G, výsledná sít morfolineamentů sloužící pro návrh zjednodušené zlomové sítě, mapováním vymezené litologické hranice neogénu a interpretační body geofyzikálního měření. 


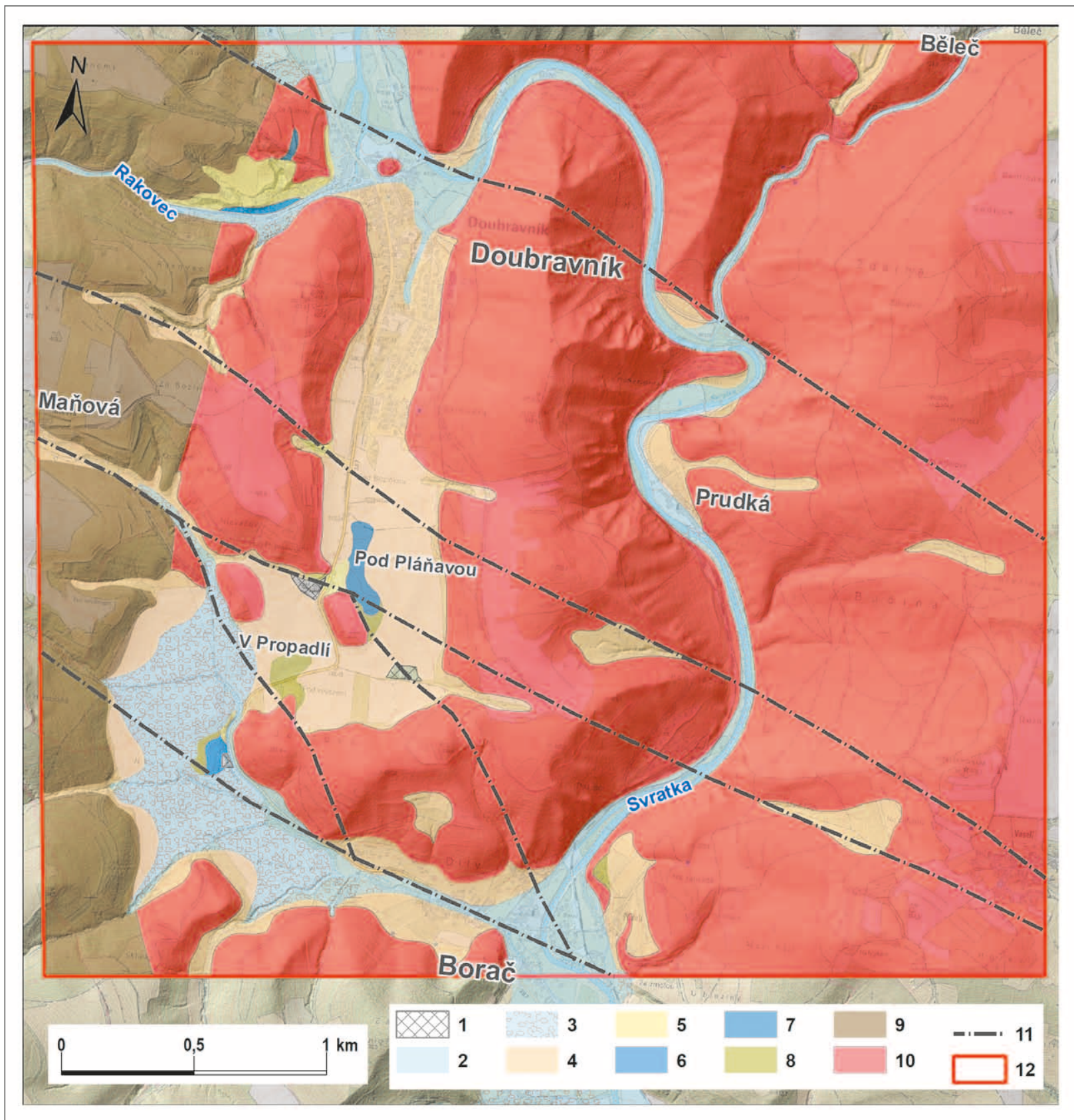

Obr. 3: Geologické schéma pokryvných útvarů s vyznačením hlavních tektonických linií. Legenda: 1 - antropogenní sedimenty; 2 - fluviální sedimenty (holocén); 3 - sedimenty výplavových kuželů (pleistocén-holocén); 4 - koluviální sedimenty (pleistocénholocén); 5 - spraše (svrchní pleistocén); 6 - fluviální sedimenty teras (střední pleistocén); 7 - fluviální sedimenty teras (spodní pleistocén); 8 -jíly (spodní baden); 9 - horniny svrateckého krystalinika; 10 - krystalinické horniny moravika; 11 - př̀edpokládaná pozice nejvýznamnějších zlomových linií; 12 - hranice zájmového území.

Fig. 3: Geological map of sedimentary cover with main tectonic lines. Legend: 1 - anthropogeneous deposits; 2 - fluvial deposits (Holocene); 3 - alluvial fans deposits (Pleistocene-Holocene); 4 - colluvial deposits (Pleistocene-Holocene); 5 - loess (Late Pleistocene); 6 - fluvial deposits of terraces (Middle Pleistocene); 7 - fluvial deposits of terraces (Early Pleistocene); 8 - clays (Lower Badenian); 9 - Svratka Crystalline complex; 10 - Moravicum (Crystalline complex); 11 - Fault inferred; 12 - site of interest boundary.

\section{Geologická stavba}

V rámci geologických prací proběhlo také podrobné geologické mapování kenozoických sedimentů v údolí mezi Doubravníkem a Boračí, jehož výsledkem bylo (spolu s výsledky geofyzikálního měření a morfostrukturní analýzy) sestavení detailní geologické mapy zájmového území (obr. 3).

Území leží při západním okraji svratecké klenby moravika, krystalinické jednotky, která leží ve strukturním podloží západně vystupujícího moldanubika (Suess 1912; Schulmann et al. 2005). Hraniční zóna je tvořena úzkým pruhem svorů a migmatů, které patří do svrateckého krystalinka. Z hornin moravika převažují bítešské ortoruly, v jejichž nadloží směrem k západu leží pararuly s vložkami mramorů a amfibolitů. Horninové pruhy mají severojižní průběh a zapadají $\mathrm{k} Z$ pod variabilními sklony. 


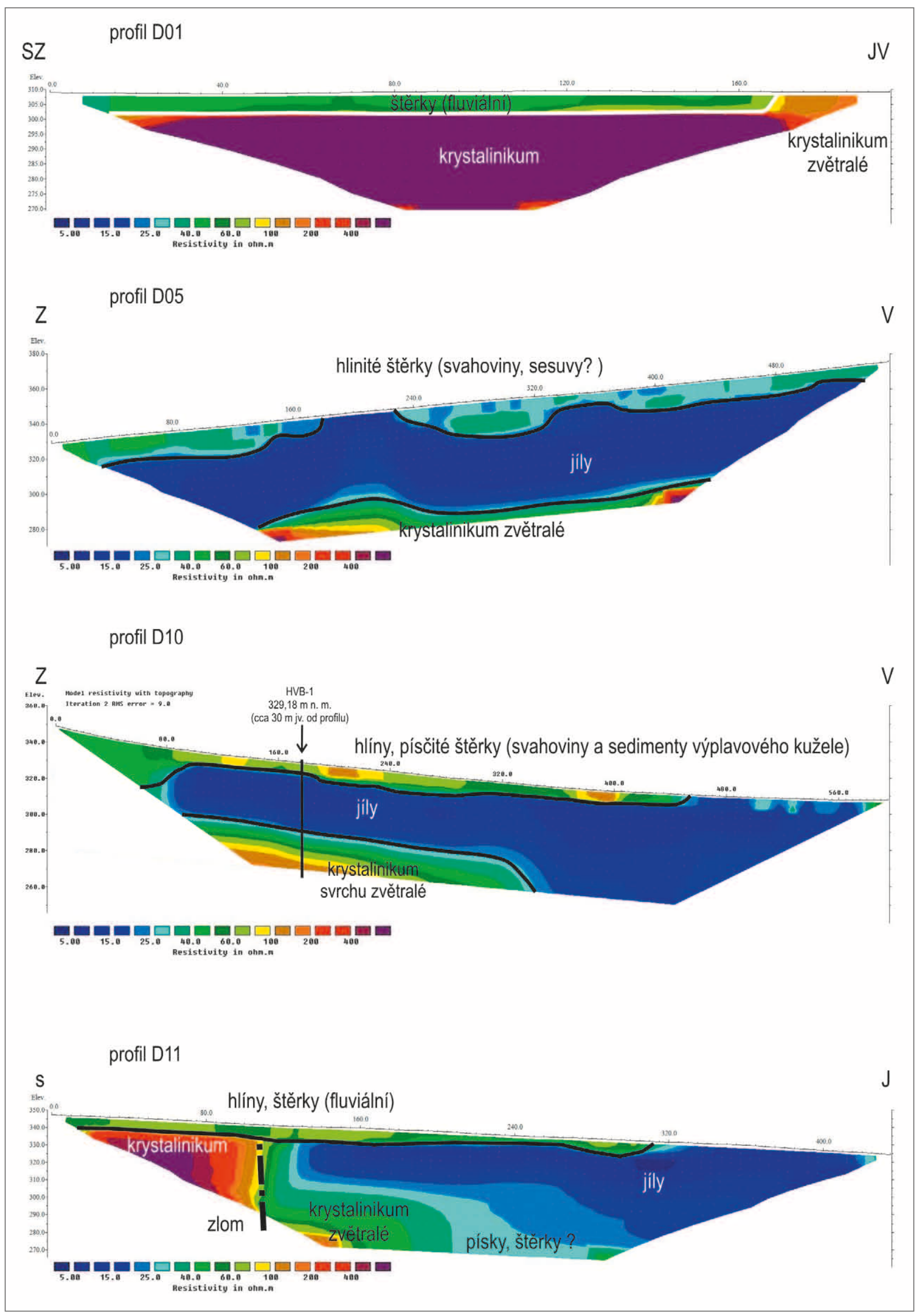

pokračování na straně 39 


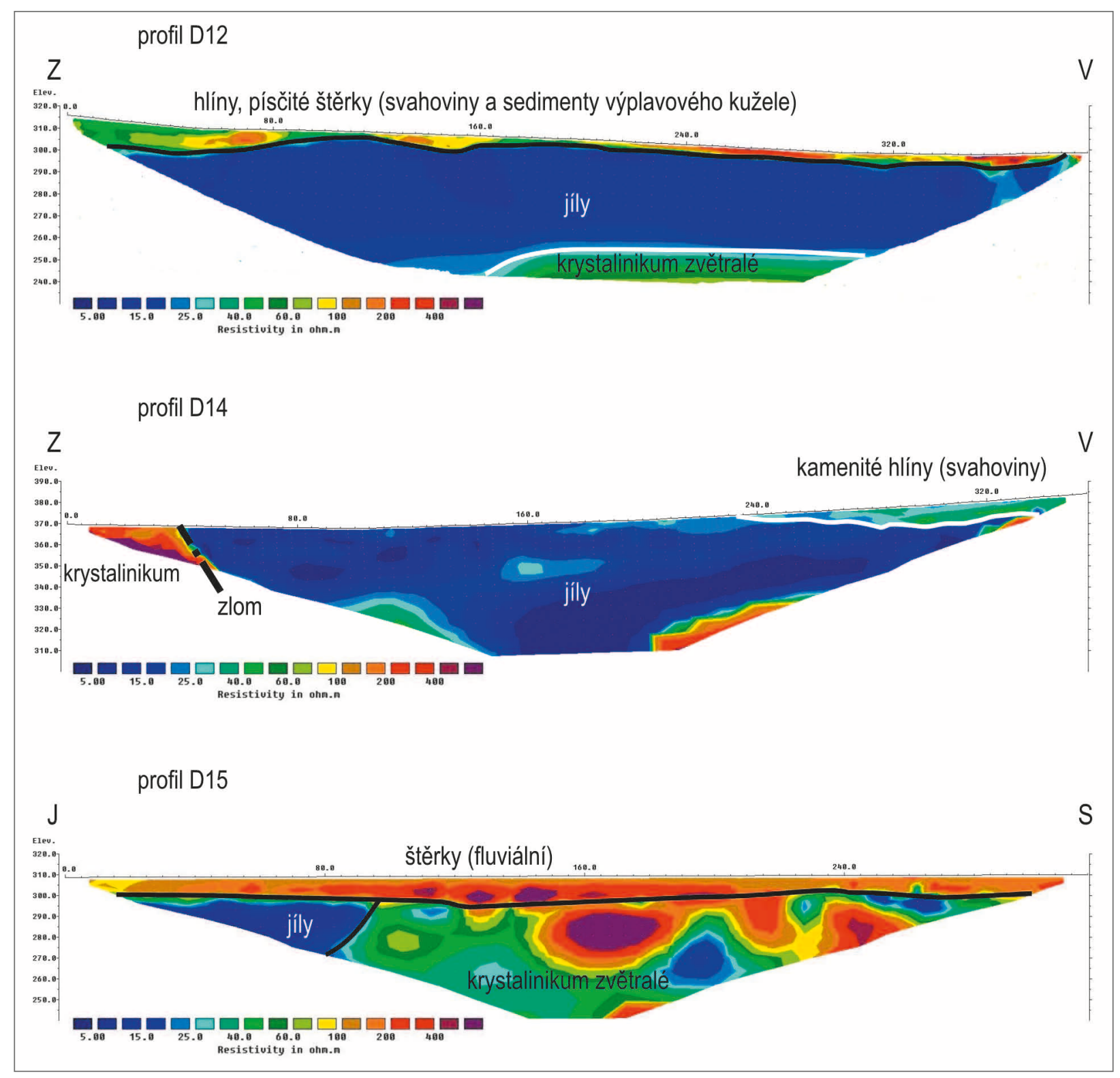

Obr. 4: Interpretace vybraných odporových řezů (pozice profilů ERT na obr. 1)

Fig. 4: Interpretation of representative resistivity model section (position of profiles in Fig. 1)

Spodnobadenské sedimenty vyplňující depresi jsou zde zastoupeny především šedými, při povrchu často rezavě skvrnitými, vápnitými slabě slídnatými jíly s hojnou mikrofaunou (Schütznerová-Havelková 1969; Petrová et al. 2001). Na povrchu se vyskytují jen lokálně, $\mathrm{z}$ podstatné části jsou překryty mladšími sedimenty. $\mathrm{Z}$ prostoru obce Běleč (sv. roh mapy) do zájmového území, jen okrajově, zasahují mnohem písčitější neogenní sedimenty dokumentované vrtem JV-106 (Bubík 1997), u nichž však není spodnobadenské stáří prokázáno.

V jílech z okolí Borače bylo zjištěno početné diverzifikované společenstvo foraminifer s vyšším zastoupením aglutinovaných druhů [Martinottiella karreri (Cush.), Textularia pala Czjzk., T. mariae Orb., Semivulvulina deperdita (Orb.), Spirorutilus carinatus (Orb.)]. Stáŕí spodního badenu indikují druhy Martinottiella karreri (Cush.), Uvigerina macrocarinata Papp et Turn., hojněji se vyskytují Nonion commune (Orb.), Melonis pompilioides
(Ficht. et Moll), Lenticulina div. sp., Heterolepa dutemplei (Orb.), Pullenia bulloides (Orb.), Bulimina elongata Orb. a další. Ve společenstvu převažují bentické druhy nad planktonickými, spolu s foraminiferami se vyskytují fragmenty měkkýšů, ostrakodů, ostny a destičky ježovek, úlomky kostí kostnatých ryb a jehlice hub. Hlubší prostředí cirkalitorálu až batyálu potvrzují rovněž nálezy korálů od Borače (Kleprlíková a Doláková 2016).

Za nejstarší pobadenský sediment lze považovat terasový štěrk v sedle Pod Pláňavou, kterým prochází i silnice Borač-Doubravník. Štěrky se nacházejív nadmořské výšce kolem $375 \mathrm{~m}$. Vzhledem k relativní výšce nad dnešním tokem Svratky lze uvažovat o jejich pliocenním stáŕí nebo v př́padě úvahy o vlivu tektoniky o stáŕí spodnopleistocenním (v případě, že by k pohybu hrástové struktury docházelo ještě v kvartéru, s čímž by mohl souviset i přesun řeky do dnešní pozice). Stáří dalších nalezených terasových štěrků je odhadováno podle jejich relativních 
výšek nad dnešním tokem. Jsou to ty, které byly nalezeny na hřbetu na sz. okraji Doubravníku v nadmořské výšce $340 \mathrm{~m}$ (tj. v relativní výšce $30 \mathrm{~m}$ ). Jejich spodnopleistocenní stárí je proto více než pravděpodobné. $V$ prrípadě štěrků tvořící terasu podél potoka Rakovce a dále štěrků uložených na terase zahloubené do badenských sedimentů v distální části výplavových kuželů Boračského potoka a jeho přítoků, v nadmořské výšce kolem 320 m, je možné předpokládat, že se jedná o sedimenty střednopleistocenního stárí. Většina spraší a sprašových hlín pokrývající závětrné (především jihovýchodní) svahy je podle zřejmé superpozice stáří svrchnopleistocénního, jsou ale většinou překryty sedimenty výplavových (aluviálních) kuželů, splachových depresí a svahovinami (koluvii). Tyto jsou spolu s fluviálními sedimenty dnešních toků výsledkem sedimentace $s$ přesahem do holocénu (recentu). Celkově jsou mocnosti kvartérních sedimentů poměrně malé, pouze v př́padě sedimentů výplavových kuželů a fluviální výplně údolního dna řeky Svratky, by mohlo jít až o $10 \mathrm{~m}$.

\section{Geofyzikální měření a jejich interpretace}

V odporovém řezu ERT se výrazně projevují kontrastní litologické rozdíly, které umožňují poměrně přesně interpretovat mocnost neogenních sedimentů, průběh reliéfu krystalinika a popř. pozici tektonických linií. Výsledky měření profilů metodou ERT jsou textově a formou interpretovaných obrázků prezentovány níže (obr. 4 - profily D01, D05, D10, D11, D12, D14 a D15), zbývající část měřených profilů i s popisem je uvedena $\mathrm{v}$ elektronické př́loze - profily: D02, D03, D06, D08, D13 a D16. Pozice všech profilů je uvedena na obrázku 1.

Nejseverněji situovaný profil D01 v obci Doubravník (obr. 1) zachytil velmi dobře reliéf nezvětralého krystalinika v hloubce do $5 \mathrm{~m}$ se zdánlivým měrným odporem 100-600 $\Omega \mathrm{m}$ (obr. 4). Snížené odpory v okrajových částech $(\sim 50 \Omega \mathrm{m})$ nejspíše indikují štěrky v bývalém korytě Rakovce (metráž $0 \mathrm{~m}$ ) a na opačné straně se jedná o zvětralé horniny v podloží terciérních jílů, které byly zastiženy profilem D02. Větší část při povrchu je tvořena fluviálními štěrky.

Profil D05 byl situován ve směru podélném s depresí, ve snaze zastihnout řez s maximální hloubkou (cca $63 \mathrm{~m}$ ) v co největší délce. Terciérní jíly s měrným odporem 5-25 $\Omega$ m byly zachyceny v celé mocnosti cca $40 \mathrm{~m}$. Výsledky je možné interpretovat tak, že ve spodní části bylo zastiženo krystalinikum se dvěma elevacemi, z nichž západněji situovaná je pohřbeným hřbetem, který je zřejmý i z povrchového mapování. Profil tedy zastihl zákrut deprese s důležitou informací, že zvětralé krystalinikum (nebo není vyloučena i štěrková výplň) se nachází v nadmořské výšce cca $290 \mathrm{~m} \mathrm{n}$. m. Na povrchu byly zachyceny $\mathrm{v}$ mocnostech až $10 \mathrm{~m}$ svahoviny se zdánlivými měrnými odpory kolem $60 \Omega \mathrm{m}$. Jejich tvary spolu s jíly naznačují, že by se mohlo jednat i o erodované části sesuvných akumulací.

Severně od Borače byly měřeny 2 profily, severnější D10 a jižněji situovaný D12. Profil D10 je nejdelší z měřených profilů $(595 \mathrm{~m})$. Byl lokalizovaný přes celou šiřku údolí a na $\mathrm{V}$ byl ukončen u asfaltové silnice
Doubravník-Borač, za níž se již nachází výchozy krystalinika. Na začátku profilu jsou při povrchu zachyceny sedimenty výplavového kužele a svahoviny (50-90 $\Omega \mathrm{m})$, pod nimi vrstva jílovitých sedimentů (5-20 $\Omega \mathrm{m})$ s mocností okolo $30 \mathrm{~m}$ a níže pak krystalinické podloží. Dál směrem $\mathrm{k} \mathrm{V}$ je již údolí hlubší, než je hloubkový dosah metody $(60 \mathrm{~m})$ a je vyplněno jílovitými sedimenty. Jak bylo naznačeno výše, tento profil bylo možné jako jediný korelovat s geologickým profilem, a to s vrtem HBV-1, jehož litologie byla popsána v kapitole „Úvod“. Z pozice vrtu a situace měřeného profilu (viz obr. 1) je zřejmé, že vrt nereprezentuje úplný sled terciérní výplně, protože zastihl podloží ve „visuté“ části údolí. Jeho hydrogeologický význam je tedy omezený pouze na podzemní vodu vázanou na krystalinické horniny.

Profil D11 začínal v údolí drobného potoka tekoucího od Maňové směrem $\mathrm{k}$ silnici. Údolíčko má neobvykle ploché dno a je poměrně široké. Profil měl ověřit, zda do něj nezasahují neogenní jíly a bylo by tedy předbadenského založení. Tato hypotéza se nepotvrdila, protože $\mathrm{z}$ výsledků měření je spíše zřejmé, že prvních $110 \mathrm{~m}$ jsou pod fluviálními sedimenty (o mocnosti cca $5 \mathrm{~m}$ ) horniny krystalinika, které je strmě ukončeno tektonickou poruchou, s poklesem asi $30 \mathrm{~m}$, druhá strmá tektonická porucha nebo spíše svah zahloubenější části údolí je indikována ve druhé třetině profilu, kde je podloží ve větší hloubce než dosah metody ERT (níže 265 m n. m.). Hlavní část údolí je opět vyplněna jílovitými sedimenty (5-30 $\Omega \mathrm{m})$.

Profil D12 je nejijižněji situovaný a směřoval přes celou jeho šíŕku údolí až k asfaltové silnici DoubravníkBorač. Na západě začínal ve svahu, kde se na povrchu nalézají svahoviny nedalekého krystalinika. V této části údolí je krystalinické podloží mimo dosah metody, tj. $60 \mathrm{~m}$, ale ve střední části profilu jsou v hloubce $50 \mathrm{~m}$ zachyceny vrstvy s měrným odporem 50-60 $\Omega \mathrm{m}$. Ty mohou představovat jak zvětraliny podloží, tak i možné fluviální štěrky. I tak je zřejmé, že v nejhlubší části je dno deprese v hloubce větší než $240 \mathrm{~m} \mathrm{n}$. m.

Ve střední nejvýše položené části „suchého údolí“ Doubravník-Borač byly situovány 2 profily. Jeden podél svahu na jeho v. straně (D13), druhý kolmo na osu údolí (D14).

Na osu deprese kolmý profil D14 prochází od morfologicky zřejmé elevace krystalinika na $Z$ pod výrazné svahy na $\mathrm{V}$. Na svém konci se křížil s výše zmíněným profilem D13. Profil D14 zachytil na svém začátku (z. strana) ostře ukončené podloží. Toto místo je interpretováno jako zlom a od něj $\mathrm{k}$ V situovaná deprese je patrně velmi hluboká a přesahuje hloubkový dosah metody, tj. $60 \mathrm{~m}$. Je vyplněná jílovitými sedimenty s velmi malým měr ným odporem $(5-20 \Omega \mathrm{m})$. Dno deprese je tedy níže než $305 \mathrm{~m}$ n. m., tj. minimálně v úrovni hladiny Svratky v Doubravníku.

Nejseverněji měřený profil D15 v blízkosti fotbalového hřiště v Doubravníku měl za cíl zjistit situaci v údolní nivě řeky Svratky s. od kostela v Doubravníku. Patří $\mathrm{k}$ hůře interpretovatelným profilům, nicméně $\mathrm{v}$ místech kontrastních přechodů vyšších odporů kolem $200 \Omega \mathrm{m}$ 


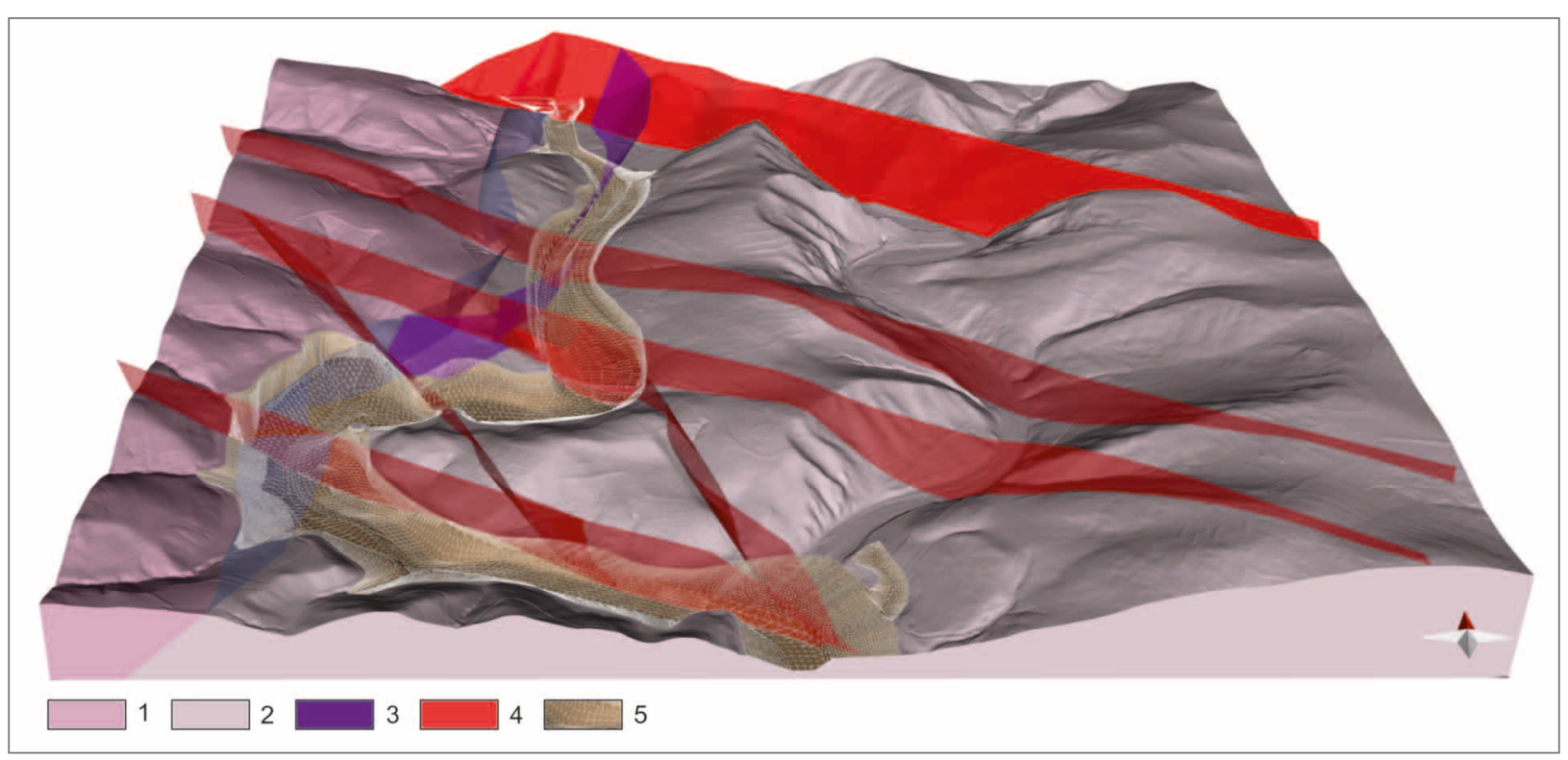

Obr. 5: 3D model paleoúdolí koryta řeky Svratky v úseku mezi obcemi Doubravník a Borač v náhledu od J. Legenda: 1 - svratecké krystalinikum; 2 -moravikum; 3 - násunové zlomy; 4 - zlomy; 5 - terciérní výplň a báze paleoúdolí.

Fig. 5: 3D model of the paleo-valley of the Svratka riverbed in the section between the villages of Doubravník and Borač in a view from the south. Legend: 1 - Svratka Crystalline complex; 2 - Moravicum (crystalline complex); 3 - thrust faults; 4 - faults; 5 tertiary infilling and the base of the paleo-valley.

při povrchu a minimálních (i kolem $5 \Omega \mathrm{m}$ ) v hloubce, je zřejmé, že se jedná o kvartérní štěrky o mocnosti do $10 \mathrm{~m}$ překrývající miocenní jíly o značné mocnosti. Ostatní části profilů s vyššími odpory reprezentují nejspíše různě zvětralé podložní horniny, případně poruchu ve směru S-J, kterou dnešní údolí při erozi využilo. Nejhlubší část údolí s terciérními jíly v tomto místě mění pozici tím, že se esovitě přesouvá ze z. strany současného údolí na stranu východní.

\section{Výsledný 3D model}

3D model zobrazuje tvar paleoúdolí koryta řeky Svratky v úseku mezi obcemi Doubravník a Borač (obr. 5). Umožňuje zvlášṫ zobrazovat jednotlivé zlomové struktury, reliéf moravika, svrateckého krystalinika a neogenních sedimentů, vlastní modelované paleoúdolí a vstupní interpretační body geofyzikálních měření. Prostorový model paleoúdolí je zasazen do současného reliéfu. V modelu jsou zobrazeny základní zlomy, které dokreslují celkovou tektonickou složitost zájmového údolí. Mezi nejstarší zlomy patří násunové struktury $\mathrm{k} Z$ pod úklonem cca $45^{\circ}$, které oddělují svratecké krystalinikum od moravika. Tyto násuny jsou porušeny zlomy směru SZ-JV se sinistrální složkou pohybu. Mezi těmito zlomy v jz. části modelu jsou vymodelovány dva dílčí zlomy směru SSZ-JJV, které $s$ předešlým systémem zlomů porušují modelované paleokoryto řeky Svratky (obr. 5).

3D model umožnil vizualizovat zjištěné skutečnosti a vytvořit tak prostorovou představu o pozicích jednotlivých segmentů paleoúdolí. Snadněji tak bylo možno odvodit genezi a funkci současného zkoumaného údolí v prostoru mezi Doubravníkem a Boračí. 3D model je dostupný na https:/geology.maps.arcgis.com/ home/webscene/viewer.html? webscene $=$ c2bbd 5 de2 $\mathrm{clc}$ 4f13b34119add56501e7 (a další z ČR: www.geology.cz/3d).

\section{Závěr a nástin geologického vývoje}

V oblasti mezi Doubravníkem a Boračí byl pomocí metod DPZ - morfostrukturní analýzy digitálního modelu reliéfu (DMR 4G) a analýzy DMR 5G, geofyzikálního měření metodou ERT a geologického mapování zpřesněn rozsah sedimentárních výplní a prostorově vymodelován reliéf povrchu krystalinika - deprese v úseku mezi obcemi Doubravník a Borač.

Práce potvrdily, že se jedná o území vyplněné především vápnitými badenskými jíly, $\mathrm{v}$ mocnostech převyšujících původní předpoklady (30 m ve vrtu HBV-1). $\mathrm{Na}$ odporových řezech ERT představují tyto jíly vrstvy s velmi nízkými odpory (5-25 $\Omega \mathrm{m})$, což je zjištěná hodnota měrného odporu např. také pro miocenní jíly na lokalitě Štěpánovice (Skácelová et al. 2016) nebo v Hornomoravském úvalu pro pliocenní jíly na lokalitách Kožušany a Dub nad Moravou (Bábek et al. 2018). Mezi Doubravníkem a Boračí tvoří nejhlubší tvar reliéfu krystalinika, jehož pozice je v rámci dnešního tvaru reliéfu různá a jeho šířka nepřesahuje $200 \mathrm{~m}$. Okolní části představují zbytek staršího údolního tvaru, který tvoří skalní terasy s výrazně menší mocností terciérního pokryvu. Podobná situace je i v přímých částech údolí Svratky s. i j. od tohoto zájmového území (mezi Nedvědicí a Doubravníkem a mezi Boračí a Štěpánovicemi), a proto se zdá být představa jejího vzniku jako předbadenského paleoúdolí řeky Svratky velmi pravděpodobná. Údolí bylo ale $\mathrm{v}$ průběhu badenské transgrese nebo po ní rozděleno tektonickými poruchami (směru SZ-JV a SSZ-JJV) do několika segmentů. Jako nejvýraznější se jeví tektonická zóna $\mathrm{v}$ prostoru mezi obcí Borač a Maňová. Tato se v interpretovaných výsledcích měření ERT projevuje skokovou změnou v mocnosti vápnitých jílů, když na profilu D05 bylo dno údolí zastiženo cca v $285 \mathrm{~m} \mathrm{n}$. m., zatímco $\mathrm{z}$ dalších profilů směrem $\mathrm{k}$ Borači je jisté, že nadmořská 
výška dna je o 30-50 m nižší. Druhým projevem této tektonické zóny je nápadné zúžení té části deprese (místně zvané V Propadlí - viz obr. 3), která je vyplněná terciérními jíly a je tedy tektonicky vyzvednuta. Ani v tomto úseku však nejsou mocnosti terciérních jílů zanedbatelné, protože jejich povrch stoupá na rozvodí (na obrázku 3 je toto místo označováno jako Pod Pláňavou), kde patrně dosahují kolem 70-80 m. Př́mo na rozvodí není situace př́liš jasná vzhledem $\mathrm{k}$ mocnostem sedimentů, které překračují možnosti použitých metod, ale i tak v profilu D14 dosahuje jílová výplň minimálně ke kótě 305 m, tedy pod úroveň nivy řeky Svratky v Doubravníku, kde nebylo možné aplikovat geofyzikální práce $\mathrm{v}$ dostatečném rozsahu kvůli husté zástavbě. Výjimkou byl krátký profil D02, $\mathrm{z}$ něhož se dá předpokládat přímé pokračování badenské sedimentární výplně i do údolí Svratky, ale pouze přes část údolí situovanou z. od kostela Povýšení Sv. Kříže v Doubravníku, protože v profilu D01 jv. od kostela bylo skalní podloží zastiženo již v hloubce cca $5 \mathrm{~m}$.

Překvapivě velké mocnosti badenských jílů neumožnily použitým metodám dosáhnout bazálních částí výplně a tedy posoudit litologický charakter dnových sedimentů. Neexistence hrubších klastických sedimentů ve výplni deprese bývá považována za důkaz jejího čistě tektonického původu (Hrádek 1980). Z tohoto výzkumu je zřejmé, že pro tvrzení o absenci těchto sedimentů není dostatek údajů, a naopak Polák (1960) zmiňuje výskyt písčité vrstvy s artézskou vodou na bázi jílů v Nedvědici. Také geofyzikální měření na vodním zdroji v jv. části Doubravníku prokázalo $\mathrm{v}$ rámci jílovitých sedimentů písčité vrstvy s mocností až 5 m (Hruška 1991). Tyto 2-5 m mocné vrstvy byly indikovány uvnitř jílůn, zvětralé ruly (s měrnými odpory 30-100 $\Omega \mathrm{m}$ ) tvořily polohy uvnitř masivu krystalinika a byly interpretovány jako puklinové pásmo. Zde je to $\mathrm{v}$ pozici dna staršího údolního tvaru.

Z hydrogeologického pohledu je zřejmé, že posilový hydrogeologický vrt HBV-1 není situován do nejhlubší části údolí. Druhým závažným faktem z pohledu dotace rajonu 2242 - Kuřimská kotlina podzemní vodou se zdá, že dno nejhlubší části terciérního údolního tvaru není v Doubravníku vyzdviženo nad úroveň nivy. Také výrazné porušení podložních hornin na kontaktu svrateckého krystalinika a moravika, které bylo zjištěno profily D15 a D16 u fotbalového hřiště v Doubravníku, zcela jistě umožňuje nepřerušený přetok podzemní vody pod izolátorem badenských jílů. Je tak více než pravděpodobné, že i území Doubravník-Nedvědice je přímou součástí hydrogeologického rajonu Kuřimská kotlina (2242) a tedy zdrojovou oblastí infiltrací podzemní vody.
Kromě hydrogeologicky aplikovatelných poznatků přispělo zpřesnění rozsahu neogenních jílů (obr. 1) k vymezení úseků silnice II/387 náchylných ke svahovým pohybo̊m. V minulosti byla silnice ohrožována zavalením přímo v obci Doubravník (Hubatka 1996). Z nových výsledků se jako potencionálně problematický jeví úsek přibližně v polovině trasy Borač-Doubravník, kde byl ve výrazně stoupajícím úseku mezi kótami $330-350 \mathrm{~m} \mathrm{n}$. m. (místní názvy V Propadlí a Pod Vývozem) veden profil D05. Z jeho interpretace vyplývá, že povrchová část jílů spolu se svahovými sedimenty, tvoří struktury vzniklé patrně svahovými procesy.

Pro interpretaci geologického vývoje se zdá být důležité zjištění, že nejhlubší část údolí tvoří pouze část údolního tvaru lemovaného plošinami s výrazně menší mocností terciérního pokryvu. Tyto plošiny by mohly být dnem staršího údolního tvaru spodnomiocénního stáří. Výše zmíněná nejhlubší část by pak byla výsledkem zahloubení paleotoku řeky Svratky, k němuž došlo v důsledku vyklenutí souvisejícího s nasunováním Karpat, které předcházelo badenské transgresi (Brzobohatý 2002). Podobně i Hypr (1981) uvažoval v souvislosti s vývojem jeskynních úrovní v Moravském krasu o erozní fázi, kterou klade těsně před transgresi moravu, nejspíše do karpatu. Během spodního badenu došlo $\mathrm{k}$ postupnému zasedimentování reliéfu do výšky prvních stovek metrů (Brzobohatý 1997). Někdy v této době a době, která následovala po ústupu badenského moře, došlo k tektonickým pohybům, které původní údolní tvar rozdělily do několika segmentů. Následná denudace reliéfu probíhala za změněných náklonů ker, kdy toky tekoucí na povrchu badenských sedimentů snadno mohly měnit svou pozici a nalézat původní údolní tvary jiných toků. $\mathrm{Na}$ „spojkách“ mezi nimi docházelo k epigenetickému zahlubování, jehož dokladem je zcela nový úsek toku Svratky Doubravník-Prudká (Žížala a Vilímek 2011). Právě díky přesunutí toku Svratky do původně malého údolí dnešního Bělečského potoka se v úseku paleoúdolí řeky Svratky zachovaly miocenní sedimenty o mocnosti téměř $100 \mathrm{~m}$, zatímco v aktivním pokračování na S i na J je mocnost maximálně poloviční.

\section{Poděkování}

Předložená práce vznikla v rámci interního projektu ČGS č. 310340, které je součástí DKRVO/ČGS (2018-2022). Autoři děkují Ing. Vladimíre Krejčí za technickou pomoc při zpracování geologické mapy a Ing. Janu Knotkovi (oba ČGS) za výpomoc přri měrení ERT profilu. Rovněž vděčí editorovi doc. Mgr. Milanovi Geršlovi, Ph.D., a recenzentưm prof. Mgr. Ondřejovi Bábkovi, Dr., a RNDr. Pavlovi Kalendovi za podnětné připominky. 


\section{Literatura}

Bábek, O., Sedláček, J., Novák, A., Létal, A. (2018). Electrical resistivity imaging of anastomosing river subsurface stratigraphy and possible controls of fluvial style change in a graben-like basin, Czech Republic. - Geomorfology, 317, 139-156.

Brzák, M. (2001). Př́spěvek ke genezi suchého údolí mezi Doubravníkem a Boračí ve Svratecké hornatině. - Acta Musei Moraviae, Scientiae geologicae, LXXXVI, 175-181.

Brzobohatý, R. (1997). Paleobatymetrie spodního badenu karpatské předhlubně na Moravě z pohledu otolitových faun. - In: Hladilová, S. (ed.): Dynamika vztahů kontinentálního a marinního prostředí, Sborník příspěvků. MU Brno.

Brzobohatý, R. (2002). Karpatská předhlubeň. - In: Chlupáč, I., Brzobohatý, R., Kovanda, J., Stráník, Z. (eds): Geologická minulost České republiky, 346-353. - Academia. Praha.

Bubík, M. (1997). O miocénu z vrtů na trase vodovodního přivaděče Vír-Brno. - Zprávy o geologických výzkumech v roce 1996, $30,64-66$.

Cahlíková, Z. (2012). Borač - posilový vrt pro obecní vodovod. - Závěrečná zpráva hydrogeologického průzkumu. MS Geofond. Praha.

Demek, J. (1972). Manual of Detailed Geomorphological Mapping. - Academia. Praha.

Hrádek, M. (1980). Význam reliéfu v přírodním systému krajiny Svratecké vrchoviny. - Zprávy Geografického ústavu ČSAV, 17, $4,147-160$.

Hruška, J. (1991). Zpráva o geofyzikálním průzkumu. Doubravník - vodní zdroj. - MS Archív ČGS Praha.

Hubatka, F. (1996). Zpráva o geofyzikálním měření na lokalitě Doubravník. - MS Archív ČGS Praha.

Hypr, D. (1981). Jeskynní úrovně v severní a střední části Moravského krasu. - Sborník Okresního muzea v Blansku, XII/1980, 65-79.

Jelínek, J. (2008). Morfotektonická analýza digitálního modelu reliéfu - vhodný prostředek pro vyhledávání zón křehkého porušení horninového masivu. - GeoScience Engineering, 54, 1-14.

Kleprlíková, L., Doláková, N. (2016). Spodnobadenští solitérní korálnatci podřádu Caryophyllida (řád Scleractinia) z lokality Borač (jižní část karpatské předhlubně, Česká republika). - Acta Musei Moraviae, Scientiae geologicae, 101, 1-2, 75-86.

Novák, V. J. (1924). Morfologický vývoj neogénních sníženin na Moravě. - Věstník královské české společnosti nauk, třída matematicko-př́rodovědecká $8,1-229$. Praha.

Petrová, P., Vít, J., Čtyroká, J. (2001). Okrajové vývoje sedimentů karpatské předhlubně na listech map 1:25 000 Blansko a Tišnov. - Scripta Facultatis Scientiarum Naturalium Universitatis Masarykianae Bruneneis, 30, Geology, 55-64.

Polák, A. (1960). Bylo u nás také moře?. - Nerostné bohatství Bystřicka, 10-11.

Sedlák, J. (2006). Gravimetrické mapování české republiky 1:25000 a jeho geologická interpretace. Oblast Ždárské vrchy - severovýchodní okraj třebíčského masívu. - MS Archív ČGS Praha.

Schütznerová-Havelková, V. (1969). Miocén v údolí Svratky sz. od Tišnova. - Časopis pro mineralogii a geologii, 14, 3-4, 305-314.

Suess, F. E. (1912). Die moravischen Fenster und ihre Bezienhung zum Grungebirge des Hohen Gesenkes. - Denkschriften (Osterr. Akad. Wiss.), Math.-naturwiss. K1., 88, 541-631.

Schulmann, K., Kroner, A., Hegner, E., Wendt, I., Konopásek, J., Lexa, O., Štípská, P. (2005). Chronological constraints on the pre-orogenic history, burial and exhumation of deep-seated rocks along the eastern margin of the Variscan orogen, Bohemian Massif, Czech Republic. American Journal of Science, 305: 407-448.

Skácelová, Z., Vít, J., Hroch, T., Karous, M., Nikl, P., Hrutka, M., Votoček, R. (2016). Geofyzikální metody v kenozoických hydrogeologických strukturách. - EGRSE, No.1, 2016, 44-54. ISSN 1803-1447 (CD-ROM).

Vít, J., Tomanová Petrová, P., Skácelová, Z., Hrutka, M. (2017). Geologická stavba hydrogeologického rajonu 2242 (Kuřimská kotlina) a představy vývoje toku řeky Svratky v kenozoiku. - Zprávy o geologických výzkumech, 50, 173-180.

Žížala, D., Vilímek, V. (2011). Morfostrukturní analýza údolí Svratky v okolí Doubravníku. - Informace České geografické společnosti, $1,30,1-12$. 